Kocaeli Journal of Science and Engineering

\title{
Size of Earthquakes
}

\author{
Mehveş Feyza Akkoyunlu 1, * \\ ${ }^{1}$ Regional Earthquake-Tsunami Monitoring Center, Kandilli Observatory and Earthquake Research Institute, Istanbul, 34684, Turkey, \\ ORCID: 0000-0002-4966-8218
}

Article Info

Review paper

Received : July 17, 2020

Accepted : October 25, 2020

Keywords

Earthquakes,

Earthquake Size,

Intensity,

Magnitude,

Macroseismic Intensity Scale

\begin{abstract}
Earthquake size is one of the most fundamental source parameters used in seismic catalogs. A reliable measure of the "size" of an earthquake is essential for seismological, geological, engineering, and scientific research. The size of a seismic source is measured using two parameters; damage caused (intensity) and energy released (magnitude). Intensity describes the strength of a seismic event in terms of human recognition, affected region, damage to structures. Intensity scales are valuable not only for the pre-instrumental period for historical earthquakes but also for seismic risk analysis. The intensity scale is classified by macroseismic scales. Intensity depends on local geological conditions, distance from the source that make the objective estimates difficult. The concept of magnitude was introduced by Richter to provide an objective measure of earthquake size. The advent of seismic recording systems made it possible to determine the strength of a seismic event from instrumental data. The magnitude of an earthquake provides quick information on the strength of a seismic event for the public and are essential for cataloging. Changes in instrumentation and magnitude formulation resulted from the calculation of different magnitude scales. In order to obtain a non-saturating uniform magnitude scale, seismic moment magnitude (Mw) is developed based on source parameters.
\end{abstract}

\section{Introduction}

Macroseismic intensity scales represent the intensity of ground-motion in terms of human observation, damage to buildings, or other observed effects at a certain location. Felt reports and damage in an area are sources of intensity estimation of an earthquake. Macroseismic intensities are important for historical seismicity and assessment of seismic hazard risk studies. Intensity depends on many factors such as local geological conditions, distance, and depth of the earthquake. The energy released from a seismic source may be may be amplified or diminished by ground motion. Macroseismic intensity classifies the severity of earthquakes depending on damage at different locations and felt shaking records. These factors are affected by the quality of construction and the density of the population [1].

\footnotetext{
* Corresponding Author: feyza.ocal@boun.edu.tr
}

An instrumental scale was necessary to characterize the size of a seismic event based on instrumental records. According to Richter (1935) "In the course of a historical or statistical study of earthquakes in a given region, it is frequently desirable to have a scale for rating these shocks in terms of their original energy, independently of the effects which may be produced at any particular point of observation" [2].

The advent of seismic recording instruments led to quantifying the strength of a seismic event by the amplitude of the recorded signal. The magnitude concept was first proposed in the 1930s by Wadati in Japan and Richter in California. The magnitude of an event is a number that characterizes the relative size or amount of energy released by an event which is independent of the place of observation. Magnitudes are derived from ground motion amplitudes and periods or from signal duration obtained from instrumental records and source parameters of the earthquake including seismic waves. 


\section{Macroseismic Intensity Scales}

The size of seismic sources is characterized by the macroseismic intensity scale before the advent of seismic recording instruments. The intensity or macroseismic intensity is an integer quantity that depends on earthquake distance, ground conditions, and strength of shaking. Intensities are defined in macroseismic scales.

The first studies took place in Italy at the end of the $18^{\text {th }}$ century. The Ten-degree Rossi-Forel scale (1883) was the first scale to be used internationally. The first 12-degree scales were introduced by Sieberg, and Mercalli, Cancani and Sieberg (1912, 1923, 1932, MCS scale). The Modified Mercalli Scale (MM scale) was revised by Richter in 1956 (MM56 scale) and used in the USA. In Europe, MSK-scale is developed by Medvedev, Sponheuer, and Karnik (1964) was widely used. In 1988 MSK-scale is revised by European Seismological Commission and European Macroseismic Scale (EMS-98) is released in 1998 and widely adopted all over the world. Earthquake intensities in Japan contain 7-degree (later upgraded to 10-degree) by Japan Meteorological Agency (JMA). Macroseismic intensity is dependent on the local geological conditions, the distance from the source, quality of the construction and, density of the population.

The intensities generally decrease with distance from the source and are site-dependent. They represent the severity of ground-motion during a seismic event on the basis of observational effects of the region, human perception, and damage to buildings.

Intensity is a measure of the strength of the seismic source and a description of common observations of an earthquake. Instead of describing the effect of an earthquake-like "the event was felt by very few people indoors", the shaking is shortly defined as "intensity 2". Each intensity degree is expressed by a series of diagnostic that describes the effects of ground motion. Intensity data are mapped in contour lines for different degrees called isoseismals. The largest observed intensity is the epicentral intensity $I_{0}$ near to the epicenter or barycenter of the highest intensities. The most recent scales are the Modified Mercalli Scale (MMI) and European Macroseismic Scale (EMS-98) which are easily adaptable for the use to building stock anywhere in the world. In Table 1, MMI Scale of Stover and Coffman edited by Musson is shown as an example for the intensity scale [3].
Table 1. MMI Scale of 1993 (Stover and Coffman, after Wood and Neumann, edited by Musson).

\begin{tabular}{|c|c|}
\hline I & $\begin{array}{l}\text { Not or rarely felt under especially } \\
\text { favourable circumstances. Under certain } \\
\text { conditions, at and outside the boundary of } \\
\text { the area in which a great shock is felt: } \\
\text { sometimes birds, animals, reported uneasy } \\
\text { or disturbed; sometimes dizziness or nausea } \\
\text { experienced; sometimes trees, structures, } \\
\text { liquids, and bodies of water may sway, } \\
\text { doors may swing very slowly. }\end{array}$ \\
\hline II & $\begin{array}{l}\text { Felt by few sensitive, or by nervous persons } \\
\text { indoors, especially on upper floors. Also, as } \\
\text { in grade I, and often more noticeably: } \\
\text { sometimes hanging objects may swing, } \\
\text { especially when delicately suspended; } \\
\text { sometimes trees, structures, liquids, bodies } \\
\text { of water may sway; doors may swing very } \\
\text { slowly; sometimes birds, animals reported } \\
\text { uneasy or disturbed; sometimes dizziness or } \\
\text { nausea experienced. }\end{array}$ \\
\hline III & $\begin{array}{l}\text { Usually rapid vibration motion felt indoors } \\
\text { by several people. Sometimes not } \\
\text { recognized to be an earthquake at first. } \\
\text { Continuity estimated in some cases. } \\
\text { Vibration occures due to the passing of } \\
\text { light, or lightly loaded trucks, or heavy } \\
\text { trucks some distance away. Hanging objects } \\
\text { may swing slightly. Movements may be } \\
\text { appreciable on upper levels of high } \\
\text { structures. Rocked standing motor cars } \\
\text { slightly. }\end{array}$ \\
\hline IV & $\begin{array}{l}\text { Felt by all. Many get frightened. Trees and } \\
\text { bushes shake slightly. Buildings shake } \\
\text { moderately to heavily. Walls creak loudly. } \\
\text { Observers described the shaking as "strong." } \\
\text { Few get awakened, especially light sleepers. } \\
\text { No one is frightened, unless apprehensive } \\
\text { from previous experience. Vibration } \\
\text { happens due to the passing of heavy or } \\
\text { heavily loaded trucks. Sensations like } \\
\text { heavy body striking building or falling of } \\
\text { heavy objects are seen inside. Rattling of } \\
\text { dishes, windows, doors; glassware and } \\
\text { crockery clink and clash. Hanging objects } \\
\text { swung, in numerous instances. Liquids in } \\
\text { open vessels disturb slightly. Standing } \\
\text { motor cars rock noticeably. }\end{array}$ \\
\hline
\end{tabular}


Table 1. (Cont.) MMI Scale of 1993 (Stover and Coffman, after Wood and Neumann, edited by Musson).

V Buildings tremble during the quake. Dishes, glassware break to some extent. Windows crack - in some cases, but not generally. Vases, small or unstable objects overturne in many instances. Hanging pictures fall. Doors, shutters, open, or close abruptly. Pendulum clocks stop, start or run fast, or slow. Small objects, furnishings, move the latter to a slight extent. Trees, bushes, shake moderately to strongly. People have difficulty in standing or walking. People feel moderately in moving vehicles.

VI Damage is slight in poorly built buildings. Fall of plaster is seen in a small amount. The plaster layer cracks somewhat, especially fine cracks in chimneys in some instances. Dishes, glassware, in considerable quantity, also some windows break. Fall of knickknacks, books, pictures. Furniture overturne in many instances. Furnishings of moderately heavy kind move. Small bells ring - church, chapel, school, etc. The intensity can only be assessed as VI if damage to buildings is observed, unless many small objects fall from shelves or many glasses or dishes break.

VII Damage neglected in buildings of good design and construction, from slight to moderate in well-built ordinary buildings, considerable in poorly built or badly designed buildings, adobe houses, old walls (especially where laid up without mortar), spires, etc. Chimneys get cracked to a considerable size, and walls to some extent. Fall of plaster in considerable to large amount, also some stucco. Numerous windows and some furniture break. Loosened brickwork and tiles shake down. Weak chimneys break at the roofline (sometimes roofs damaged). Fall of cornices from towers and high buildings. Bricks and stones dislodge.
Table 1. (Cont.) MMI Scale of 1993 (Stover and Coffman, after Wood and Neumann, edited by Musson).

VIII Slight damage in structures (bricked) built especially to withstand earthquakes. Partial collapse considerable in ordinary substantial buildings. Wooden houses rack, tumble down in some cases, panel walls in frame structures thrown out, and decayed pilings break off. Fall of walls. Solid stone walls crack and break seriously. Chimneys, columns, monuments, also factory stacks, towers fall or twist. Very heavy furniture move or overturn conspicuously. Trees shake strongly - branches, trunks, break off, especially palm trees.

IX Damage considerable in (masonry) structures built especially to withstand earthquakes: break of some plumb woodframe houses built especially to withstand earthquakes; great extent damage in substantial (masonry) buildings, some collapse in large part; or wholly shifted frame buildings off foundations and racked frames.

X Damage serious to dams, dykes, embankments. Severe to well-built wooden structures and bridges, some destroyed. Dangerous cracks develop in excellent brick walls. Most masonry and frame structures, as well as their foundations, destroy.

XI Damage severe to wood-frame structures, especially near shock centres. Great to dams, dikes, embankments often for long distances. Few, if any (masonry) structures remained standing. Destroyed large wellbuilt bridges by the wrecking of supporting piers, or pillars. Less affected yielding wooden bridges.

XII Total damage - practically all parts of construction wholly damage or destroy. 
The simplified short form of EMS-98 (abstracted) [3] is shown in Table 2.

Table 2. Short Description of EMS-98 (Abstracted).

\begin{tabular}{|c|c|c|}
\hline I & Not felt & Not felt \\
\hline II & Scarcely felt & $\begin{array}{l}\text { Felt only by very few } \\
\text { individuals at rest in their } \\
\text { homes. }\end{array}$ \\
\hline III & Weak & $\begin{array}{l}\text { Felt indoors by a few people. } \\
\text { People at rest feel a swaying } \\
\text { or light trembling. }\end{array}$ \\
\hline IV & $\begin{array}{l}\text { Largely } \\
\text { observed }\end{array}$ & $\begin{array}{l}\text { Felt by many people indoors, } \\
\text { but by very few outdoors. A } \\
\text { few people are awakened. } \\
\text { Windows, doors and dishes } \\
\text { rattle. }\end{array}$ \\
\hline $\mathbf{V}$ & Strong & $\begin{array}{l}\text { Felt by most indoors, by few } \\
\text { outdoors. Many sleeping } \\
\text { people wake up. A few are } \\
\text { frightened. } \\
\text { tremble in the meantime. } \\
\text { Hanging objects swing } \\
\text { considerably. Small objects } \\
\text { are shifted. Doors and } \\
\text { windows swing open or shut. }\end{array}$ \\
\hline VI & $\begin{array}{l}\text { Slightly } \\
\text { damaging }\end{array}$ & $\begin{array}{l}\text { Many people are frightened } \\
\text { and run outdoors. Some } \\
\text { objects fall. Some houses } \\
\text { suffer slight non-structural } \\
\text { damage like hair-line cracks } \\
\text { and fall of small pieces of } \\
\text { plaster. }\end{array}$ \\
\hline VII & Damaging & $\begin{array}{l}\text { Most people are frightened } \\
\text { and run outdoors. Furniture } \\
\text { is shifted and objects fall } \\
\text { from shelves in large } \\
\text { numbers. Many well-built } \\
\text { ordinary buildings suffer } \\
\text { moderate damage: small } \\
\text { cracks in walls, fall of } \\
\text { plaster, parts of chimneys } \\
\text { fall down; older buildings } \\
\text { may show large cracks in } \\
\text { walls and failure of fill-in } \\
\text { walls }\end{array}$ \\
\hline VIII & $\begin{array}{l}\text { Heavily } \\
\text { damaging }\end{array}$ & $\begin{array}{l}\text { Many people find it difficult } \\
\text { to stand. Many houses have } \\
\text { large cracks in walls. A few } \\
\text { well-built ordinary buildings } \\
\text { show serious failure of } \\
\text { walls, while weak and older } \\
\text { ones may collapse. }\end{array}$ \\
\hline
\end{tabular}

Table 2. (Cont.) Short Description of EMS-98 (Abstracted).

\begin{tabular}{|c|c|c|}
\hline IX & Destructive & $\begin{array}{l}\text { General panic. Many weak } \\
\text { constructions collapse. Even } \\
\text { well-built ordinary buildings } \\
\text { show very heavy damage: } \\
\text { serious failure of walls and } \\
\text { partial structural failure. }\end{array}$ \\
\hline $\mathbf{X}$ & $\begin{array}{l}\text { Very } \\
\text { destructive }\end{array}$ & $\begin{array}{l}\text { Many ordinary well-built } \\
\text { buildings collapse. }\end{array}$ \\
\hline XI & Devastating & $\begin{array}{l}\text { Most ordinary well-built } \\
\text { buildings collapse; even } \\
\text { some with good earthquake } \\
\text { resistant design are } \\
\text { destroyed. }\end{array}$ \\
\hline XII & $\begin{array}{l}\text { Completely } \\
\text { devastating }\end{array}$ & $\begin{array}{l}\text { Almost all buildings are } \\
\text { destroyed. }\end{array}$ \\
\hline
\end{tabular}

Macroseismic data is gathered by several methods. The main source of the data is the collection of the questionnaires. The questionnaires are important to collect data from a large number of observations. A web-based program called "Did you Feel It?" by USGS [4] is an international questionnaire. Field studies should be held to collect information on earthquake damages of the buildings. [5]. In Figure 1, the intensity map of 24 January 2020 Sivrice-Elazığ earthquake is given as an example [6].
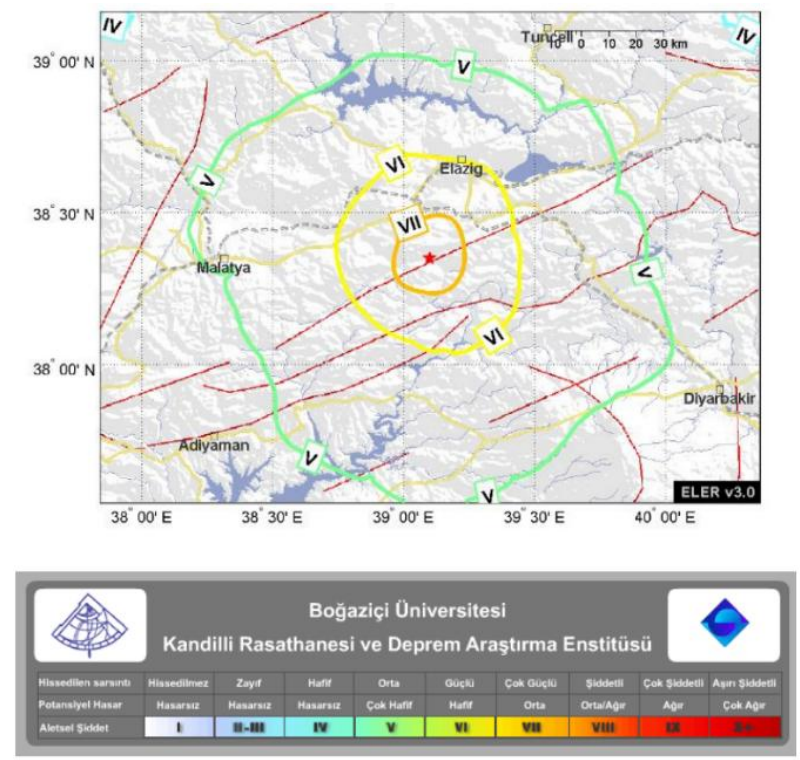

Figure 1. Screenshot from the KOERI website, showing a macroseismic display of 24 January 2020 SivriceElazığ earthquake.

\section{Earthquake Magnitude Scales}

Earthquake magnitude is a parameter used in seismology to quantify the size of an earthquake based on 
the measurement of the maximum ground motion recorded by a seismograph. There is no scale limitation to magnitudes as in macroseismic intensity scales. Magnitudes are commonly derived from ground motion amplitudes and periods or from duration of seismic signals measured on instrumental records. The same earthquake might have different magnitude values on different scales. The magnitude scales above are dependent on a certain signal frequency.

The magnitude of an event is based on and corrected for the decay of amplitudes with epicenter distance and source depth.

Charles F. Richter (1935) introduced Richter magnitude [7] or local magnitude $\left(\mathrm{M}_{\mathrm{L}}\right)$ and defined it as:

"The magnitude of a shock is defined as the logarithm of the calculated maximum trace amplitude, expressed in microns, with which standard short-period torsion seismometer $(T 0=0.8, V=2.8000, h=0.8)$ would register that shock at the epicentral distance of $100 \mathrm{~km}$ )."

Richter scale termed as ML and applicable local earthquakes are formulated as:

$M_{L}=\log A_{\max }-\log A_{0}(\Delta)$

where $A_{\max }$ is the seismogram amplitude measured on a Wood-Anderson record and the distance $\Delta$ to the source. Generally all magnitude scales are a form of

$M=\log \left(\frac{A}{T}\right)+f(\Delta, h)+C_{\text {source }}+C_{\text {receiver }}$

where $\mathrm{T}$ is the period of the signal, $f(\Delta, h)$ is a correction for epicentral distance and hypocenter depth. Empirical correction values for the source region and the receiver site are added. In Richter's formula, as all the seismographs were of the same type dependence on $\mathrm{T}$ was missing, maximum amplitude always had the same dominant period.

For global earthquake size calculations, the local magnitude scale is not practical. Gutenberg and Richter designed magnitude scales for global magnitude scales. Body-wave magnitude $\left(\mathrm{m}_{\mathrm{b}}\right)$ is calculated by maximum ground-motion amplitude of $\mathrm{P}, \mathrm{PP}$, or S body waves, and defined as

$m=\log \left(\frac{A}{T}\right)+Q(\Delta, h)$

where $\mathrm{Q}$ is an empirically determined distance and depth correction, depending on the phase used. If the body-wave magnitude is determined from $P$ wave at a period of $1 \mathrm{~s}$, it is generally abbreviated as $\mathrm{m}_{\mathrm{b}}$. When determined from long-period instruments at periods between 5-15 seconds, it is noted as $m_{B}$.
Surface wave magnitude scale uses the maximum ground motion amplitude of surface wave at a period of 20s. In general, Rayleigh wave amplitude is used for the calculation of $M_{s}$. The formula for this surface-wave magnitude is defined as

$M_{S}=\log A_{20 s}+1.66 \log \Delta+2.0$

As the size of the earthquake increases, the low-frequency part of its spectrum relative to the higher frequencies is stronger. This will cause magnitude saturation for large earthquakes. Seismic moment calculation was introduced by Kanamori [8] to provide a non-saturating magnitude scale for large earthquakes termed as moment magnitude $\left(\mathrm{M}_{\mathrm{w}}\right)$ based on seismic moment $\left(\mathrm{M}_{0}\right)$. The seismic moment $\mathrm{M}_{0}$ can be determined by seismic data, geodetic data or geological data [9].

Seismic moment can be found accurately from seismic data [9]. The seismic moment calculation constitutes the fault area, slip, and strength of the material which represents the physical measure of an earthquake. It can be obtained from amplitudes of seismic waves or from the field estimations of the slip and fault area of the earthquake. For a finite source with area of fault plane (S), on which the averaged slip is D (offset, in $\mathrm{km}$ ) and $\mu$ (Gpa) is shear or the rigidity modulus of the material surrounding the fault, the $\mathrm{M}_{0}$, scalar seismic moment is given as

$M_{0}=\mu \mathrm{DS}$

In cgs units, the seismic moment is given in dyn $\mathrm{cm}$ and in SI units it is in Nm.

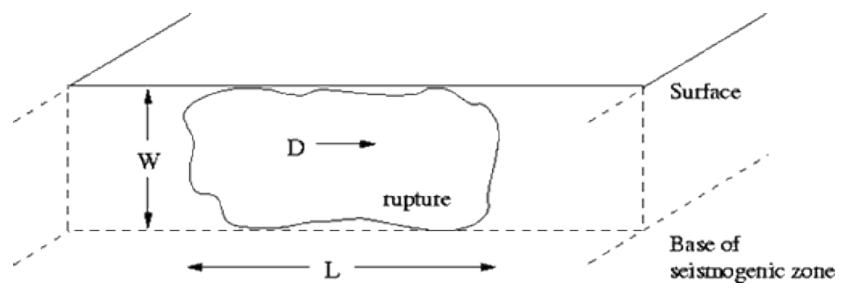

Figure 2. Diagram of an area of the fault rupture on earthquake area [10].

The moment magnitude $\left(\mathrm{M}_{\mathrm{w}}\right)$ and seismic moment $\left(\mathrm{M}_{0}\right)$ relation is defined as by the following [9]. $\mathrm{M}_{0}$ is a static parameter that does not represent dynamic properties of the source unless the use of scaling relations exist. $\mathrm{M}_{0}$ or $\mathrm{M}_{\mathrm{w}}$ can be used as a useful parameter for the earthquake damage effects [9].

$M_{w}=\frac{\log _{10} M_{0}}{1.5}-6.07 \quad\left(M_{0}\right.$ in $\left.N m\right)$

Magnitude scales are affected by not only 
observational errors but also fault geometry, size and source depth of the earthquake. The magnitude scales determined at different periods represent different parts of the seismic source spectrum. Various magnitude scales $\left[\mathrm{M}_{\mathrm{s}}, \mathrm{m}_{\mathrm{b}}, \mathrm{M}_{\mathrm{L}}, \mathrm{M}_{\mathrm{w}}\right.$ ) calculated for earthquake catalogues will be useful for research purposes [9]. As the range of period for different magnitude scale change, magnitude scales saturate differently. The relations between various magnitude scales are summarized in a graphical form representing the saturation of $m_{b}, m_{B}, M_{L}, M_{s}$ by [11-12] in Figure 2. and Figure 3.

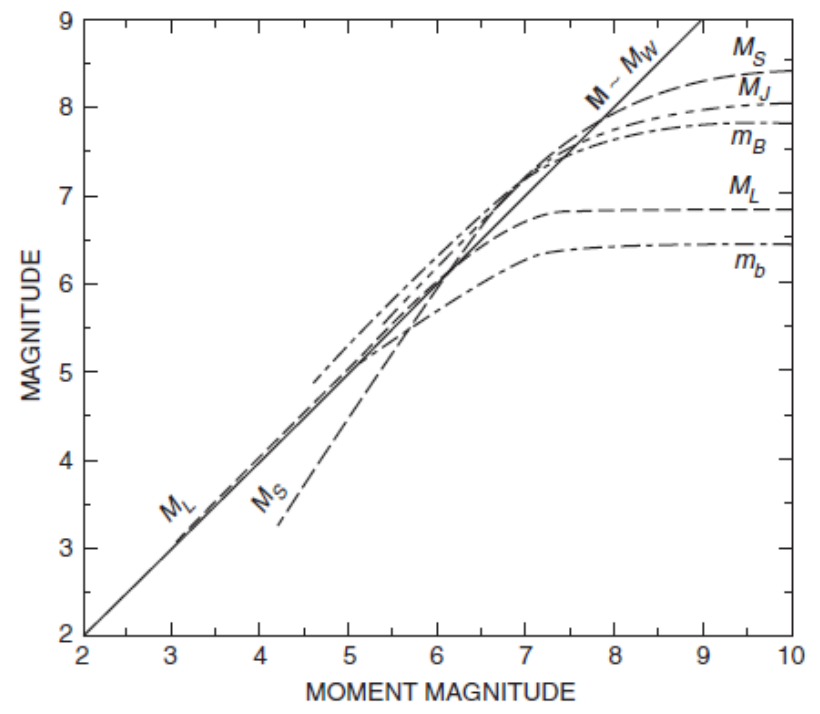

Figure 3. Relations between magnitude scales.

The range of periods of different magnitude scales is: for $\mathrm{mb}: \sim 1 \mathrm{~s}$; for $\mathrm{M}_{\mathrm{L}}$ : $\sim 0.1-3 \mathrm{~s}$ form $\mathrm{mB}$ : $\sim 0.5-15 \mathrm{~s}$; for $\mathrm{M}_{\mathrm{s}}$ : $\sim 20$ s and for Mw: $\sim 10-\infty$. For shorter periods, early saturation occurs. For instance, $\mathrm{m}_{\mathrm{b}}$ saturates around 6.5, $\mathrm{M}_{\mathrm{L}}$ around $7, \mathrm{mB}$ at 8 and $\mathrm{M}_{\mathrm{s}}$ at about 8.5. Mw magnitude does not saturate [13].

\section{Conclusions}

Size of an earthquake is one of the most fundamental earthquake source parameters of seismic catalogs. A reliable size of an earthquake is essential for engineering, tectonic studies, seismic hazard and risk assessment applications. Earthquake size is the basis of a variety of scientific research. The size of earthquakes are characterized in two different ways; macroseismic intensity scale (I) and magnitude (M).

Macroseismic intensity represents strength of the event in terms of human perception, damage to buildings and changes in the surrounding environment.

Magnitude scale is a logarithmic measure of the size of an event derived from instrumental records. The size estimates of different magnitude scales may be different for the same earthquake due to the magnitude calculation methods. There is no scale limitation to magnitudes whereas macroseismic scale is limited to 10 or 12-degree scale. Different macroseismic scales can be used in different countries depending on the regional properties. Earthquake magnitude scale is not uniform due to changes in instrumentation, the data reduction method and the magnitude formula. Various magnitude scales have been developed. The magnitude scales change with the range of period of the signal used during magnitude determination. Seismic moment magnitude is one the most reliable, uniform type of non-saturating magnitude for earthquakes derived from seismic moment that uses source parameters of the earthquake region.

\section{References}

[1] Bormann P., Wendt S., DiGiacomo D., 2013. Seismic Sources and Source Parameters. In: Bormann P. (Ed.), New Manual of Seismological Observatory Practice 2 (NMSOP2), Potsdam, Germany. https://doi.org/10.2312/GFZ.NMSOP-2_ch3.

[2] Bormann P., 2011. Earthquakes, Intensity in Encyclopedia of Solid Earth Geophysics, Springer, Dordrecht, The Netherlands.

[3] Musson R. M., Cecić I., 2012. New Manual of Seismological Observatory Practice 2 (NMSOP-2). doi.org/10.2312/GFZ.NMSOP-2_ch12.

[4] Wald D. J., Quitoriano V., Heaton T. H., Kanamori H., 1999. Relationships Between Peak Ground Acceleration, Peak Ground Velocity, and Modified Mercalli Intensity in California. Earthquake Spectra, 15(3), pp.557-564.

[5] Grünthal G., 2011. Earthquakes, Intensity in Encyclopedia of Solid Earth Geophysics, Springer, Dordrecht, The Netherlands.

[6] 24 Ocak 2020 Elazığ Sivrice Depremi Basın Bülteni, http://www.koeri.boun.edu.tr/sismo/2/wp-content/ uploads/2020/01/24_Ocak_2020_Sivrice_Elazig_Dep remi_V13.pdf. (Access Date: 23.10.2020).

[7] Richter C. F., 1935. An Instrumental Earthquake Magnitude Scale. Bulletin of the Seismological Society of America, 25(1), pp.1-32.

[8] Kanamori H., 1977. The Energy Release in Great Earthquakes. Journal of Geophysical Research, 82(20), pp.2981-2987.

[9] Kanamori H., Brodsky E. E., 2004. The Physics of Earthquakes. Reports on Progress in Physics, 67(8), pp. 1429 
[10] Earthquake Glossary Seismic moment, https://earthquake.usgs.gov/learn/glossary/?term= seismic\%20moment (Access Date: 24.10.2020).

[11] Campbell K.W., 1985. Strong Motion Attenuation Relations: a Ten-Year Perspective. Earthquake Spectra, 1(4), pp.759-804.

[12] Kanamori H., 1983. Magnitude Scale and Quantification of Earthquakes. Tectonophysics, 93(3-4), pp.185-199.

[13] Bormann P., 2002. Magnitude of Seismic Events. IASPEI New Manual of Seismological Observatory Practice, 1, pp.16-50. 